In cooperation with the National Park Service

\title{
Modeling Elk and Bison Carrying Capacity for Great Sand Dunes National Park, Baca National Wildlife Refuge, and The Nature Conservancy's Medano Ranch, Colorado
}

\author{
By Gary Wockner, Randall Boone, Kathryn A. Schoenecker, and Linda C. Zeigenfuss
}

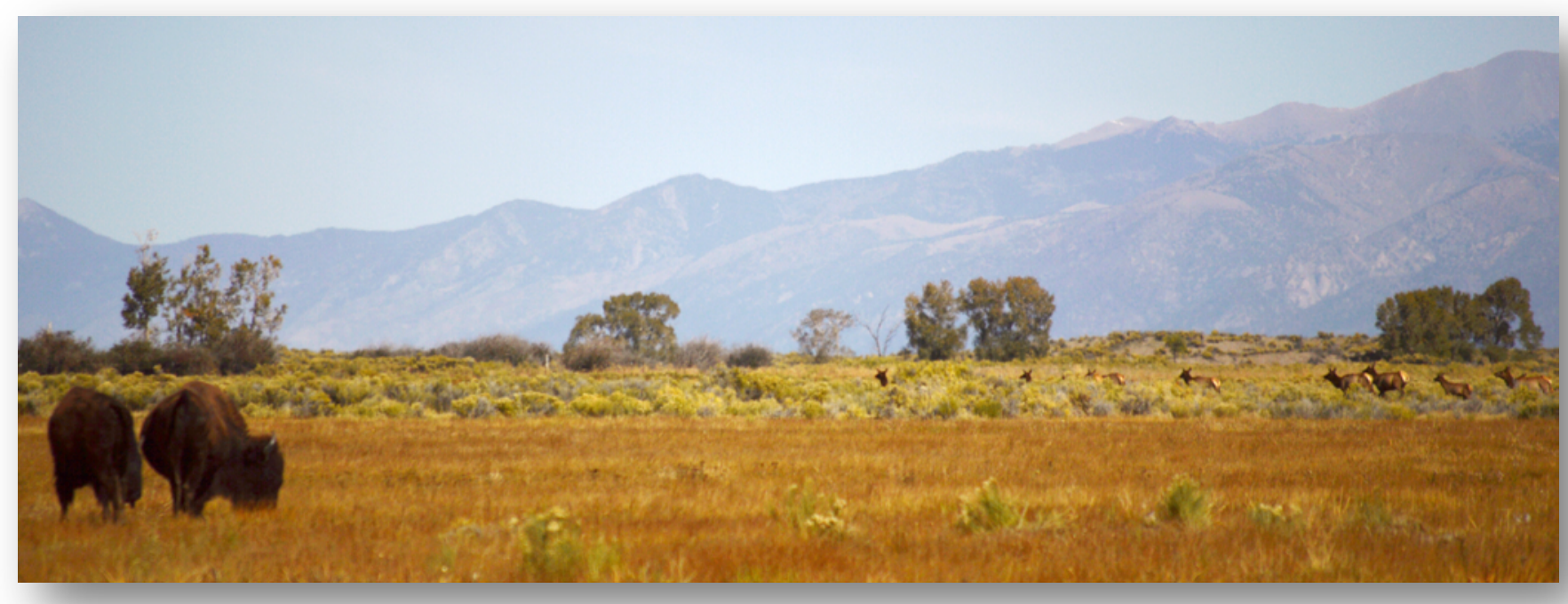

Open-File Report 2014-1200 


\section{U.S. Department of the Interior \\ SALLY JEWELL, Secretary}

\section{U.S. Geological Survey}

Suzette M. Kimball, Acting Director

\section{U.S. Geological Survey, Reston, Virginia: 2015}

For more information on the USGS-the Federal source for science about the Earth, its natural and living resources, natural hazards, and the environment-visit http://www.usgs.gov or call 1-888-ASK-USGS

For an overview of USGS information products, including maps, imagery, and publications, visit $h$ ttp://www.usgs.gov/pubprod

To order this and other USGS information products, visit $h$ ttp://store.usgs.gov

Suggested citation:

Wockner, Gary, Boone, Randall, Schoenecker, K.A., and Zeigenfuss, L.C., 2015, Modeling elk and bison carrying capacity for Great Sand Dunes National Park, Baca National Wildlife Refuge, and The Nature Conservancy's Medano Ranch, Colorado: U.S. Geological Survey Open-File Report 2014-1200, 23 p., http://dx.doi.org/10.3133/ofr20141200.

ISSN 2331-1258 (online)

Any use of trade, firm, or product names is for descriptive purposes only and does not imply endorsement by the U.S. Government.

Although this information product, for the most part, is in the public domain, it also may contain copyrighted materials as noted in the text. Permission to reproduce copyrighted items must be secured from the copyright owner. 


\section{Contents}

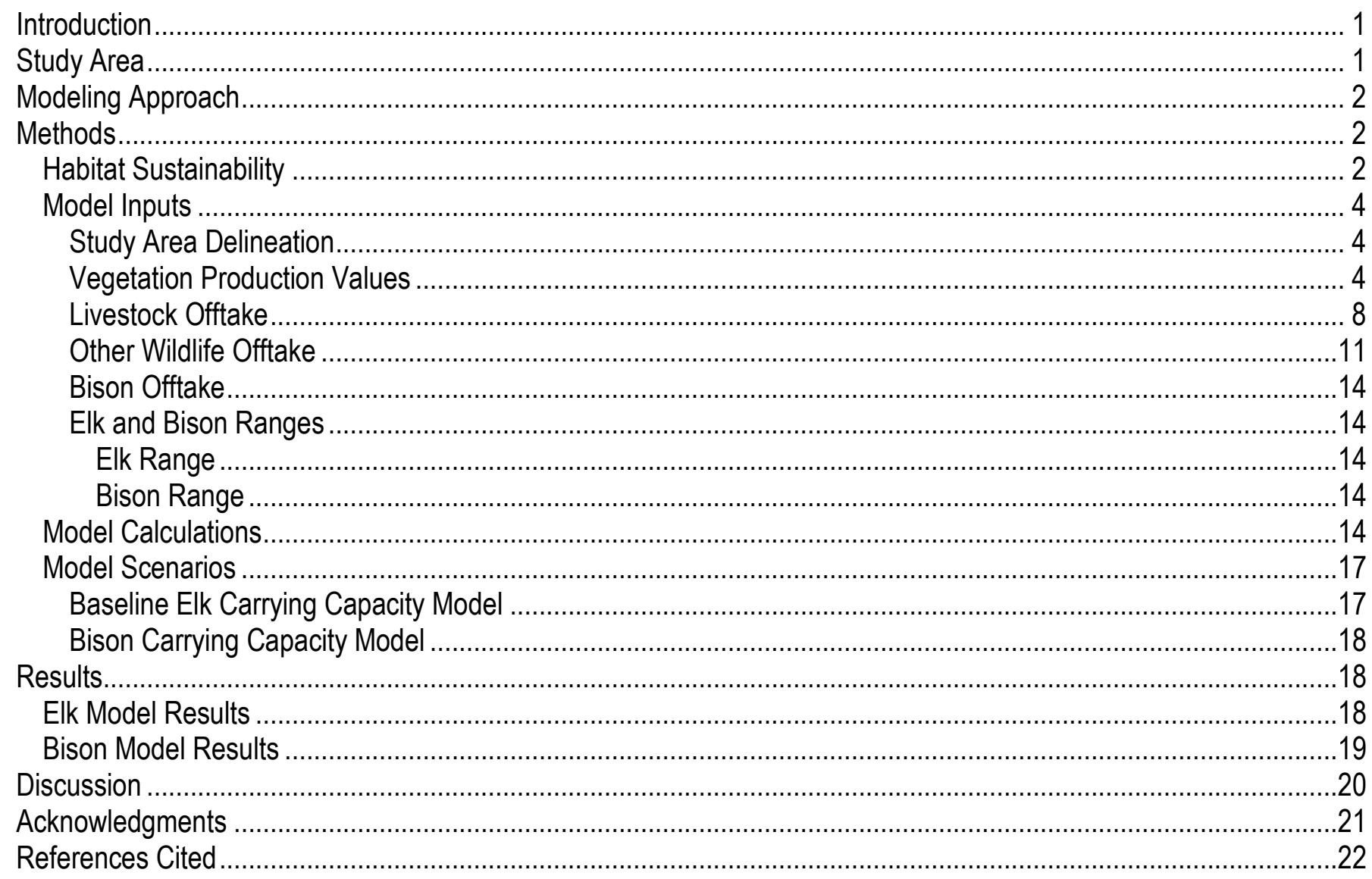

\section{Figures}

1. Map showing Colorado Parks and Wildlife game management units............................................................ 5

2. Vegetation classification map for the study area in the San Luis Valley, Colorado ............................................. 7

3. Vegetation production map for the study area in the San Luis Valley, Colorado ................................................. 9

4. Livestock offtake in $\mathrm{kg} / \mathrm{ha}$ for the study area in the San Luis Valley, Colorado ............................................... 12

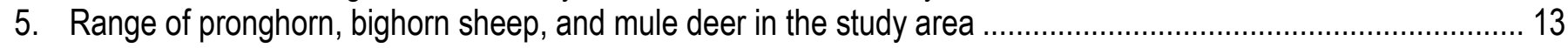

6. Elk range (area used by elk based on radio collar data) ........................................................................... 15

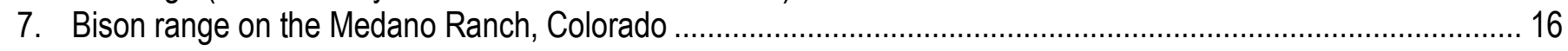

\section{Tables}

1. Ownership of land in the Great Sand Dunes ecosystem study area, and type of livestock offtake information acquired.

2. Average body weights for wild ungulates used for carrying capacity modeling ............................................... 14

3. Estimated elk carrying capacity modeled within elk range in the Great Sand Dunes/San Luis Valley, Colorado study area 
4. Estimated elk carrying capacity modeled within elk range in the Great Sand Dunes/San Luis Valley, Colorado study area using various habitat-management scenarios on the Baca National Wildlife Refuge portion of the study area......

5. Estimated elk carrying capacity modeled for only Great Sand Dunes National Park and Preserve, the Medano Ranch, and Baca National Wildlife Refuge

6. Bison carrying capacity on the Medano Ranch at varying numbers of elk

\section{Conversion Factors}

Inch/Pound to SI

\begin{tabular}{lcl}
\hline & \multicolumn{1}{c}{ Multiply } & \multicolumn{1}{c}{ To obtain } \\
\hline inch (in.) & Length & \\
inch (in.) & 2.54 & centimeter $(\mathrm{cm})$ \\
foot (ft) & 25.4 & millimeter $(\mathrm{mm})$ \\
mile (mi) & 0.3048 & meter (m) \\
mile, nautical (nmi) & 1.609 & kilometer $(\mathrm{km})$ \\
yard (yd) & 1.852 & kilometer $(\mathrm{km})$ \\
\hline & 0.9144 & meter $(\mathrm{m})$ \\
\hline acre & Area & \\
acre & 4,047 & square meter $\left(\mathrm{m}^{2}\right)$ \\
acre & 0.4047 & hectare (ha) \\
acre & 0.4047 & square hectometer $\left(\mathrm{hm}^{2}\right)$ \\
square foot $\left(\mathrm{ft}^{2}\right)$ & 0.004047 & square kilometer $\left(\mathrm{km}^{2}\right)$ \\
square foot $\left(\mathrm{ft}^{2}\right)$ & 929.0 & square centimeter $\left(\mathrm{cm}^{2}\right)$ \\
square inch $\left(\mathrm{in}^{2}\right)$ & 0.09290 & square meter $\left(\mathrm{m}^{2}\right)$ \\
section $\left(640 \mathrm{acres}^{2}\right.$ or 1 square mile) & 6.452 & square centimeter $\left(\mathrm{cm}^{2}\right)$ \\
square mile $\left(\mathrm{mi}^{2}\right)$ & 259.0 & square hectometer $\left(\mathrm{hm}^{2}\right)$ \\
square mile $\left(\mathrm{mi}^{2}\right)$ & 259.0 & hectare (ha) \\
\hline
\end{tabular}

Temperature in degrees Celsius $\left({ }^{\circ} \mathrm{C}\right)$ may be converted to degrees Fahrenheit $\left({ }^{\circ} \mathrm{F}\right)$ as follows:

${ }^{\circ} \mathrm{F}=\left(1.8 x^{\circ} \mathrm{C}\right)+32$

Horizontal coordinate information is referenced to the North American Datum of 1927 (NAD 27).

Altitude, as used in this report, refers to distance above the vertical datum. 


\title{
Modeling Elk and Bison Carrying Capacity for Great Sand Dunes National Park, Baca National Wildlife Refuge, and The Nature Conservancy's Medano Ranch, Colorado
}

\author{
By Gary Wockner ${ }^{1}$, Randall Boone ${ }^{1}$, Kathryn A. Schoenecker ${ }^{2,1}$, and Linda C. Zeigenfuss²
}

\section{Introduction}

Great Sand Dunes National Park and Preserve and the neighboring Baca National Wildlife Refuge constitute an extraordinary setting that offers a variety of opportunities for outdoor recreation and natural resource preservation in the San Luis Valley of Colorado. Adjacent to these federal lands, the Nature Conservancy (TNC) manages the historic Medano Ranch. The total land area of these three conservation properties is roughly 121,500 hectares (ha). It is a remote and rugged area in which resource managers must balance the protection of natural resources with recreation and neighboring land uses. The management of wild ungulates in this setting presents challenges, as wild ungulates move freely across public and private landscapes.

The San Luis Valley was historically used for irrigated agriculture and ranching (Simonds, 1995). Historically, livestock, including sheep (Ovis aries) and cattle (Bos taurus), were grazed throughout the valley. The former Luis Marie "Baca" Ranch, which makes up the northern part of Great Sand Dunes National Park (hereafter "Park") and all of the Baca National Wildlife Refuge (hereafter "Refuge"), was actively grazed by cattle until 2004. Bison (Bison bison), elk (Cervus elaphus), mule deer (Odocoileus hemionus), and pronghorn (Antilocapra americana) were native to the area until about the 1840s, when bison, elk, and pronghorn were extirpated (Swift, 1945; Meany and Van Vuren, 1993).

Elk and pronghorn likely moved back into the area from surrounding populations to the north and south, and mule deer populations have varied through time. A population of 4,400 elk currently inhabits the area (S. Ferraro, Terrestrial Biologist, Colorado Parks and Wildlife, oral commun., June 2014). The current bison population was established in 1986 for meat production. In 1999 TNC purchased the ranch and established a bison conservation herd, and eventually subcontracted management to a private rancher in 2005. A population of bison ranging in size from 1,200-2,000 ranges freely within the 16,100 ha Medano Ranch. Ungulate populations in the valley are regulated by hunting, with the exception of bison, which are rounded up and culled annually to maintain population levels.

In an effort to create and form the basis of a multi-agency ungulate management plan for the region, the Park sought the development of an elk and bison ecological carrying capacity model to provide guidance to resource managers.

\section{Study Area}

Our study area encompasses the eastern edge of the San Luis Valley of south-central Colorado (fig. 1) within Great Sand Dunes National Park, the Baca National Wildlife Refuge, and the Medano

\footnotetext{
${ }^{1}$ Natural Resource Ecology Laboratory, Colorado State University, Fort Collins, Colo.

${ }^{2}$ U.S. Geological Survey, Fort Collins Science Center, Fort Collins, Colo.
} 
Ranch which is owned by The Nature Conservancy. The San Luis Valley is an arid, high altitude (2,300-2,700 meters [m]) intermountain basin just east of the Continental Divide. The Medano Ranch bison range lies at the lowest point in the valley adjacent to Great Sand Dunes National Park and the Baca National Wildlife Refuge (fig. 1). Streams entering the southern portion of the study area form the headwaters of the Rio Grande. The Closed Basin portion in the north is hydrologically closed. The Sangre de Cristo Mountains along the eastern boundary of the valley extend roughly 4,000 $\mathrm{m}$ in elevation. Precipitation averages 28 centimeters annually and falls mostly during monsoonal rains in July through September. Summers are warm with average daytime temperatures ranging from 26.5 to $29.5^{\circ} \mathrm{C}$ on the valley floor. Winters are cold and dry with average valley daytime temperatures ranging from -9.5 to $1.5^{\circ} \mathrm{C}$. Eight streams in the study area flow east to west, and all of them have limited flow during the year. Streams frequently disappear underground at their lower reaches.

\section{Modeling Approach}

Our model is intended for use in the Park, the Refuge, TNC's Medano Ranch (hereafter "Ranch"), and surrounding Federal, State, and private lands in and along the Sangre de Cristo Mountains. We developed two carrying capacity models: one for elk across the eastern San Luis Valley, and one for bison solely within the fenced Medano Ranch. The model is a landscape-scale approach following methods in Hobbs and others (2003) for Wyoming, and Wockner and others (2008) for Colorado. These models provide baseline carrying capacity estimates for ungulates as well as analyze possible management scenarios that agency partners may consider.

The model was designed to be a simple, transparent tool for evaluating carrying capacity based on forage availability. Wildlife population-management decisions have typically been based on population models. These population models often incorporate minimal information regarding the feedbacks that exist between herbivory and vegetation or resource availability (Weisberg and others, 2002). The model we used applies simple forage accounting theory, and all calculations rely on straightforward arithmetic.

The approach is simplistic, beginning with a base model, and adding detail incrementally as needed to address questions unresolved by the simpler model. The model relies on existing information from local, State, and Federal government agencies, but can be more highly refined based on local field research. The inputs to our model include field measurements provided by U.S. Geological Survey (USGS) and National Park Service (NPS) over a multi-year research project (Schoenecker, 2012). The model is based on a simple principle of forage abundance, in which forage is allocated to various ungulates based on landscape scale herbaceous vegetation production and number of ungulates. The approach starts with a base layer in a geographic information system (GIS) of vegetation production, and we subtracted the amount of forage that should be left ungrazed. We then systematically removed forage for each user group (livestock, wildlife, etc.). The remaining vegetation production can be allocated to elk by calculating how many elk could be fed by the remaining forage. This same approach and methodology was used for the bison model.

\section{Methods}

\section{Habitat Sustainability}

Many factors combine to determine how much vegetation consumption can occur before a habitat is no longer sustainable. These factors include species composition, season of use, intensity of use, and prior grazing history (Coughenour, 1991). A number of studies assessed the effects of grazing 
on grasslands and shrublands from various parts of the world. A review conducted by Milchunas and Lauenroth (1993) compiled 97 of these studies encompassing 276 data sets, and produced general results for herbage consumption. In semiarid systems, when grazed versus ungrazed plots were compared, grazed plots had a mean consumption rate of aboveground net primary production (ANPP) of 35 percent. This consumption rate resulted in a moderate change in species composition from native vegetation. Holechek and Pieper (1992) showed moderate grazing intensity for different semiarid range sites varied from 25 to 50 percent, with moderate grazing for sagebrush grasslands averaging between 30 and 40 percent ANPP, depending on environmental conditions.

The model calculates the carrying capacity for elk and bison on the landscape with the goal of ensuring that the habitat remains sustainable in terms of the health of the vegetation and grazing ungulates. The "habitat sustainability threshold" is the amount of forage that must remain ungrazed and maintaining this threshold promotes habitat sustainability by not allowing all vegetation production to be consumed by ungulates. This sustainability concept was applied in Wockner and others (2008) for western Colorado as part of the Colorado Wildlife Habitat Assessment Project (http://www.nrel.colostate.edu/projects/habitat/). We used literature sources for sustainable grazing in semiarid ecosystems to inform our habitat sustainability threshold. Managers can modify the habitat sustainability threshold in response to climate conditions or other management considerations. Unlike most grazing studies that focus on the pasture or allotment scale, the habitat sustainability threshold used in our model applies to an entire landscape and encompasses numerous range-site types from an elevation of 2,200 $\mathrm{m}$ to over 4,000 m, so wide variation in vegetation production at this scale can occur.

The low and high thresholds represent theoretical lower and upper guidelines that can be used for Park and Refuge management decisions. These thresholds are based on forage use (or "offtake") averaged across the entire landscape. Some areas within the landscape will receive use above threshold levels, and others will receive little or no use. For this reason, this model is applicable at a landscape scale only because thresholds represent sustainable use levels based on the scale of an entire landscape. Periodic field monitoring and management by resource managers may be necessary to ensure habitat sustainability. Our models do not capture finer scale spatial heterogeneity in resource availability or offtake; thus, monitoring heavily-used sites would be prudent for management.

Wockner and others (2008) created a habitat sustainability threshold "range" with high, low, and midpoint thresholds. For the elk carrying capacity model, the low threshold value represents consumption of 25 percent of the total ANPP, midpoint consumption equals 28.5 percent, and the high threshold value equates to 32 percent consumption of ANPP. Thus, at the low threshold, 75 percent of ANPP remains ungrazed; at the high threshold, 68 percent of ANPP remains ungrazed; and at the midpoint, 71.5 percent of ANPP remains ungrazed. The long-standing rule of thumb used in range management is "take half, leave half." Because the model leaves so much of ANPP ungrazed, it is considered to be a very conservative model for habitat sustainability.

The bison model calculates carrying capacity for bison within the Medano Ranch. The elk model calculates carrying capacity for elk within the entire landscape (fig. 1), which varies from 2,290 $\mathrm{m}$ to 4,370 $\mathrm{m}$ in elevation. The bison model focused only on a small valley floor section of this landscape. The valley floor contains a higher percentage of vegetation types, including wet and mesic meadows that contain palatable and productive grasses. Thus, a higher habitat sustainability threshold was used as the "midpoint" and "high" threshold values in the bison model, where more of the vegetation is available to be eaten by grazing ungulates to account for the higher productivity in vegetation types found on the Medano Ranch. In the elk model, we allowed between 25 and 32 percent of the vegetation production to be grazed, and in the bison model, we allowed between 25 percent and 75 percent. This is a wide range of values that produces a wide range of results, but some justification 
for using these wider values exists. Vegetation sampling on the Ranch completed by USGS and NPS (Schoenecker, 2012) from 2005-2007 showed that average annual wildlife offtake (for bison, elk, deer, and pronghorn) on herbaceous understory plants in cottonwood communities was 70.5 percent, in wet meadows it was 64.5 percent, in willow communities it was 72 percent, and in mesic meadows it was 79 percent. Vegetation production in grazed areas of these communities was equal to or significantly higher than ungrazed (exclosed) vegetation, suggesting these high levels of offtake were sustainable, and were in fact enhancing vegetation production (Schoenecker, 2012). We sought to use a range of habitat sustainability measurements that approached those measured on the ground by research crews.

These models do not take into account variability in forage nutritional value, season of use, or habitat selection by different ungulate species. Our models are simple, and merely look at the habitat from a "raw pounds of food" perspective. More complicated models can take these factors into account, but require more fine-scale data inputs. Where available, site-specific fine-scale data can be incorporated into our models. However, in previous studies in the Yellowstone Ecosystem and in North Park, Colorado (Colo.), both simple and complex models yielded very similar results, at least in regard to ungulate carrying capacity (Weisberg and others, 2002; Singer and others, 2004).

\section{Model Inputs}

Six map layers were developed as inputs for the model: study area, vegetation production values, livestock offtake, other ungulate (pronghorn and mule deer) offtake, bison offtake, and elk range/bison range.

The modeling strategy used a step-wise progression where we first delineated the study area and determined vegetation production for the entire study area. Vegetation production was then removed from the study area to account for habitat sustainability thresholds (how much production must not be grazed), livestock offtake, other ungulate offtake, and bison offtake, in that order. All calculations were conducted using ArcView version 9 GIS software (ESRI, Inc.).

\section{Study Area Delineation}

Park-resource managers were interested in a management approach in which the Park would not be an isolated landscape but would fit into the larger ecosystem. In addition, elk movements span the entire landscape and elk presence should be modeled at a broader scale than just the Park and Refuge. Managers, including Park, Colorado Parks and Wildlife (CPW), TNC, and Refuge personnel, agreed to include two CPW game management units (GMUs) for the study, units 82 and 861, an area of roughly 335,900 ha. These two units comprise the rough outlines of the entire migration range of the elk population based on radio collar location data (K. Schoenecker, Ecologist, U.S. Geological Survey, Fort Collins Science Center, unpublished data; fig. 1). The Medano Ranch contains roughly 16,100 ha of bison range (fig. 1).

\section{Vegetation Production Values}

The models calculate a forage-based carrying capacity, thus vegetation production values drive the model. The greater the amount of vegetation available, the more elk and(or) bison can be sustained; the less vegetation available, the fewer elk and(or) bison can be sustained. We created the vegetation production map based on satellite mapping, land-cover mapping, statistical procedures, and local field research. We created both an annual forage-production map and a complete land-cover map for the study area in ArcView. 


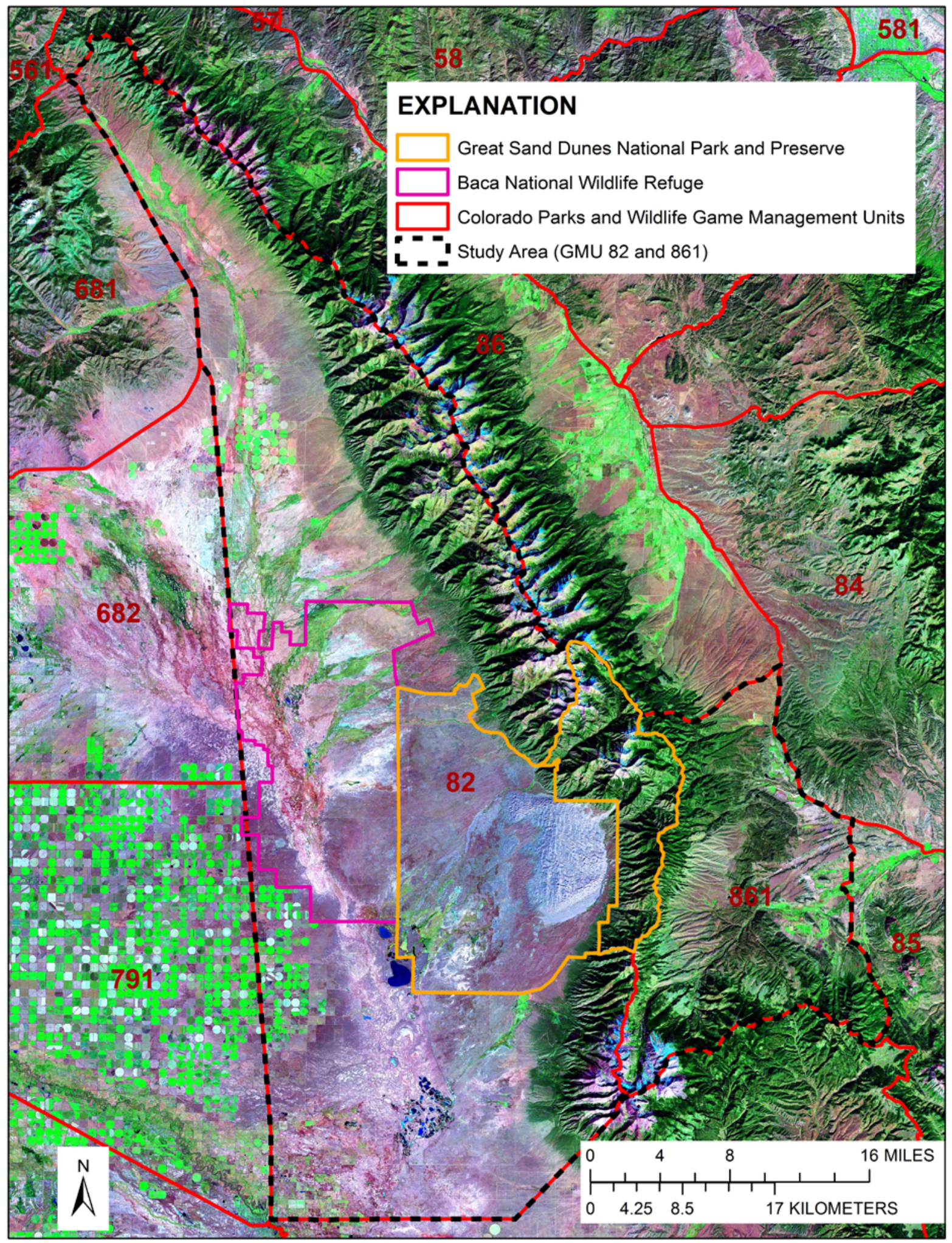

Figure 1. Colorado Parks and Wildlife game management units (GMUs), surrounding and including Great Sand Dunes National Park and Preserve, Baca National Wildlife Refuge, and The Nature Conservancy's Medano Ranch. Black dashed lines indicate study area boundary which encompasses GMUs 82 and 861. 
To determine land cover in the study area, we used a highly-detailed vegetation map developed by a cooperative group of scientists from Bureau of Reclamation (BOR), Fish and Wildlife Service (FWS), USGS, NPS, NatureServ, and Colorado State University (Salas and others, 2011). We collapsed the detailed vegetation classification from this original map into 13 vegetation types, which included 174,536 ha, or roughly 50 percent of our study area. We used the Colorado Vegetation Map (CVM) version 8 (Theobald and others, 2004) to represent areas not included in the highly-detailed map. The vegetation classes in the CVM were relabeled to correspond to the 13 classes used in this study (fig. 2). The two maps were then merged, and CVM classification was edited to improve agreement with the highly-detailed map. Specifically, some areas identified as pastures in the CVM were reclassified as wet meadows and wetlands. Also, the cottonwood and willow class appeared to be originally estimated in the CVM map using a distance-to-water measure. This overestimated coverage of this class relative to the highly-detailed map and subsequent reclassification greatly reduced this class in the portions of the study area covered only by the CVM.

After determining land cover by vegetation type, we had to assign forage production values to vegetation types. Extensive portions of the study area had Natural Resources Conservation Service (NRCS) forage production estimates mapped at a relatively fine scale (estimated from essentially county-level soils maps, known as SSURGO data; http://www.nrcs.usda.gov/wps/portal/nrcs/detail/soils/survey/?cid=nrcs142p2_05362). We used forageproduction estimates derived from USGS field measurements to estimate production in 4 of the 13 vegetation classes and compared the estimates to production estimates that were mapped by NRCS. The lower elevation areas had SSURGO data available, with 213,492 ha or 64 percent of the study area mapped. Production in high elevation areas was represented using statewide coarse-scale production estimates (STATSGO data; http://water.usgs.gov/GIS/metadata/usgswrd/XML/ussoils.xml). The alpine production estimate included data from a study conducted in central Colorado (Walker and others, 1994). All spatial surfaces were resampled to 63.61-m (1-acre) pixels.

Using NRCS data resulted in a dual resolution map of the study area with the Valley bottom lower elevations mapped in high detail and the high elevation areas mapped in very low detail. Forage production is known to be associated to physical characteristics related to remotely-sensed measures (for example, aspect, land cover, greenness as measured from satellites and gross primary production). To improve our confidence in the forage-production estimates in the high elevation portion of the study area, we conducted regression analyses to predict production for areas where fine-scale data were not available, using production estimates from the area mapped at a finer scale. In these analyses, we calculated production estimates from 16,683 randomly-located sites within the area with fine-scale production estimates as the dependent data. Independent data included elevation; slope; aspect; landcover type, percent cover of bare ground, herbs, and trees estimated from satellite images (MOD44 Vegetation Cover Conversion product derived from MODIS satellite data; http://modis.gsfc.nasa.gov/data/dataprod/dataproducts.php?MOD_NUMBER=44); reflectance in GeoCover Landsat data (bands 7, 4, and 2) from circa 2000; greenness as represented in satellite normalized difference vegetation indices (NDVI); and gross primary production estimates (MOD17 Vegetation Production, Net Primary Productivity (NPP) product derived from MODIS satellite data; http://modis.gsfc.nasa.gov/data/dataprod/dataproducts.php?MOD_NUMBER=17). Tree regression failed to yield useful results, so we used linear regression. After confirming near-normal distributions of input data, we used backward step-wise regression to create a final statistical model. This included land cover classification, elevation, slope, reflectance within GeoCover (band 3), greenness during the growing season, a tree cover estimate, and gross primary production. The final statistical model, with 


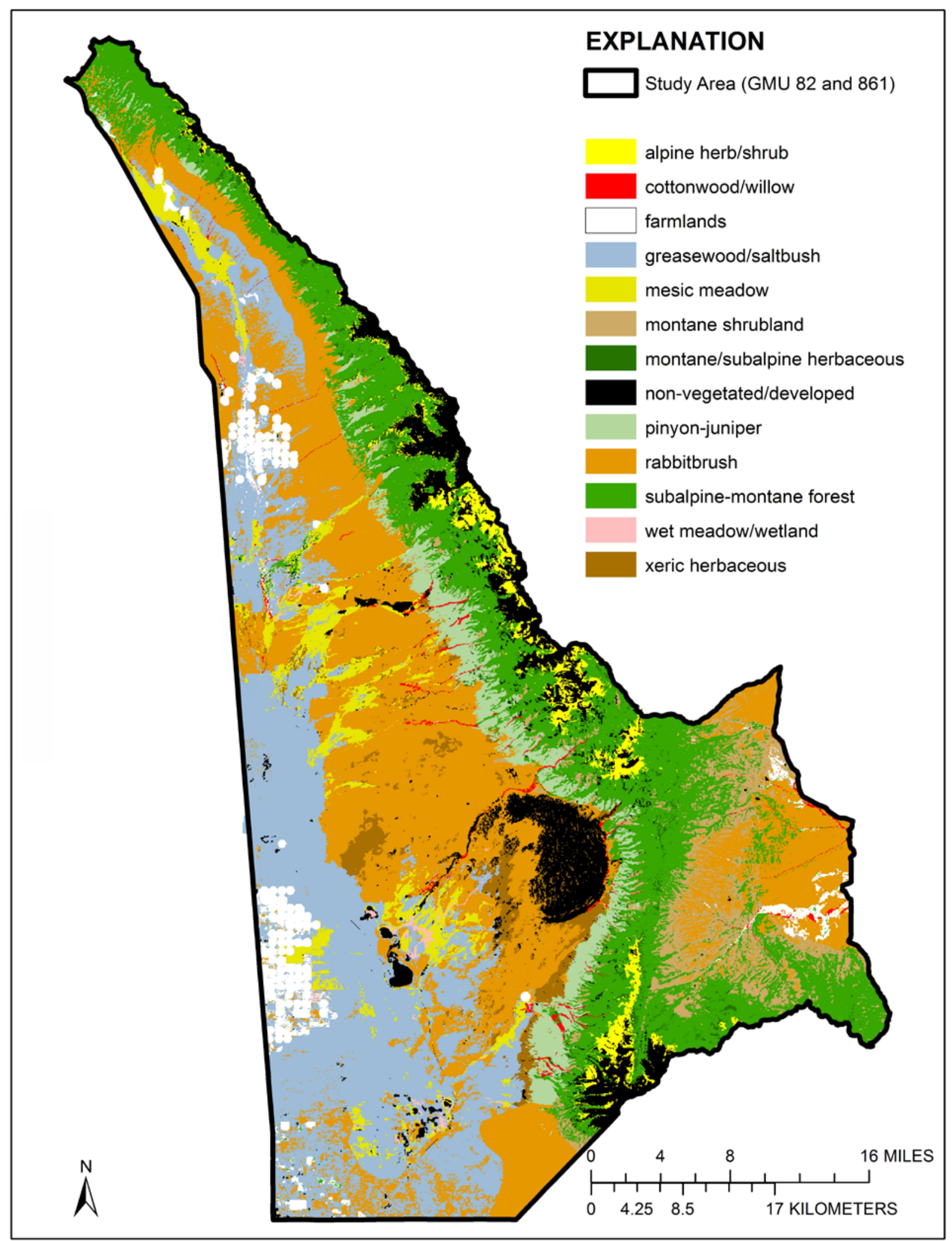

Figure 2. Vegetation classification map for the study area in the San Luis Valley, Colorado. (GMU, game management unit) 
less than 2 percent of the 16,683 samples excluded as outliers, explained 34 percent of the variation in forage production ( $P$ less than 0.001$)$.

To approximate the nature of the SSURGO production estimates, production from the regression model was classified into categories spanning $112 \mathrm{~kg} / \mathrm{ha} /$ year production (100 pounds [lbs]/acre/ year), for a total of 16 classes. The top production in lbs/acre was 1,750, so final classes used were: 125; 300; $400 ; 500 ; 600 ; 700 ; 800 ; 900 ; 1,000 ; 1,100 ; 1,200 ; 1,300 ; 1,400 ; 1,500 ; 1,600$; and 1,700. Production from the regression model was then passed through a majority filter, which replaced single isolated pixels of a given value with the majority of the neighboring pixels (the "queens" neighborhood; the eight neighboring cells including those adjacent and on diagonals from a given pixel). The final map was created by merging three data layers in a hierarchical way, so that areas with values in the first layer were used rather than those in the second or third. That is, the layers had precedence, so that the zeros in the first layer were used regardless of the content of the other two, then the second high quality SSURGO data was used wherever it was available, and lastly for the remaining (mostly high elevation) areas, the statistically-derived data were used. We merged: (1) a layer that contained zero production for areas labeled non-vegetated/developed in our land-cover map, (2) SSURGO production estimates, and (3) classified estimates from our regression analyses.

Based on research in western Colorado (Wockner and others, 2008), we found that SSURGO and STATSGO production values overestimated current production by about 20 percent, because these datasets are often a decade or more out of date. The differences in production estimates in SSURGO and STATSGO are generally due to recent invasion of weedy species and other unpalatable species, reduced precipitation in recent years, and in some cases, overstocking of livestock or wild ungulates. We therefore applied a 20 percent downward correction to the production map by multiplying its values by 0.80 , yielding the final forage production map for the study area (fig. 3 ).

\section{Livestock Offtake}

To determine offtake by livestock, we used a recent and detailed ownership map for Colorado (COMaP; Theobald and others, 2008) in which the area of interest included lands owned or managed by 13 groups (table 1). We grouped private lands into a single category and used livestock ownership numbers specific to each county from the 2007 Census of Agriculture to estimate stocking on private lands. To determine how many of the reported animals occurring in each county might occur in the study area, we merged a statewide database of forage production estimates (USDA NRCS STATSGO data) with a map of irrigated pasture lands identified in the CVM8 vegetation map (Theobald and others, 2004). We assigned production estimates of 3,360 kg/ha/year to irrigated pastures based on Theobald and others (2004). We then calculated how much of the total forage production on lands of all ownership in each county was within the study area (Alamosa $=38.1$ percent; Huerfano $=13.5$ percent; Saguache County $=23.7$ percent). These values were used to estimate the number of cattle and sheep in each county that occurred within the study area. For example, the U.S. Department of Agriculture's Census of Agriculture statistics from 1992, 1997, 2002, and 2007 showed long-term livestock populations in Alamosa County as 12,900 cattle; 1,997 sheep; and 1,066 horses (U.S. Department of Agriculture, various years). We therefore represented stocking rates on private lands of Alamosa County included in our study area as 4,916 cattle $(12,900 \times 0.381), 761$ sheep $(1,997 \times 0.381)$, and 406 horses $(1,066 \times 0.381)$. This gave us a general stocking rate for lands within each county, based on government statistics. We applied these values to the numerous parcels of private land in the area, and sought more refined estimates for the large blocks of public land.

Information for other land managers varied (table 1). Colorado Division of Wildlife (now Colorado Parks and Wildlife; CPW) and Manitou Institute owned small parcels in the study area, and 


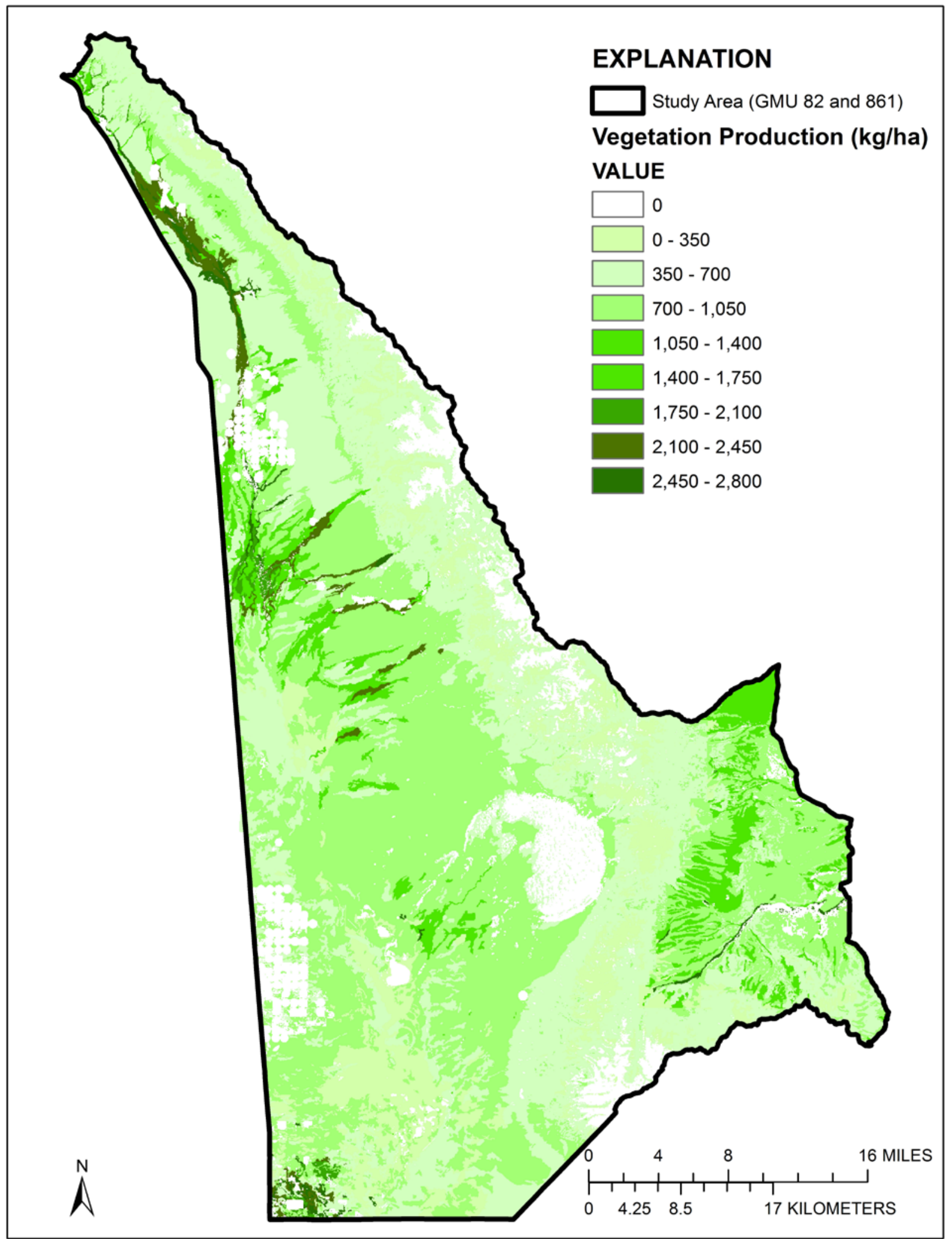

Figure 3. Vegetation production map for the study area in the San Luis Valley, Colorado. (GMU, game management unit; kg/ha, kilograms per hectare) 
stocking on those parcels was assumed to be zero. Stocking rates for State Land Board lands within our study area, were classed as 'better,' 'average,' or 'poor'; stocking ranged from 1.5-2.0 ha/AU (animal unit) to 3.2-4.0 ha/AU. Colorado State Park (now CPW) lands were not grazed by livestock. The Orient Land Trust informed us that the western portion of their parcel is a ranch managed at typical stocking rates, and the eastern portion was not grazed. The San Isabel Land Protection Trust leases 16-32 ha of land for grazing, and the remainder is not grazed; thus, a very low offtake was assigned. For livestock stocking rates on lands managed by TNC outside the bison range, a default modest offtake of 82 $\mathrm{kg} / \mathrm{ha} /$ year was used based on allotment grazing information provided by BLM personnel and Kit Page from the Colorado State Land Board.

Table 1. Ownership of land in the Great Sand Dunes ecosystem study area, and type of livestock offtake information acquired.

\begin{tabular}{|c|c|c|c|}
\hline & Land Owner or Manager & Hectares & Offtake Data Resolution \\
\hline 1 & Private & 120,420 & County-level \\
\hline 2 & $\begin{array}{l}\text { Colorado Division of Wildlife (now known as } \\
\text { Colorado Parks and Wildlife) }\end{array}$ & 6 & Small, not pursued \\
\hline 3 & Colorado State Land Board & 30,299 & By quadrant \\
\hline 4 & $\begin{array}{l}\text { Colorado State Parks (now known as Colorado } \\
\text { Parks and Wildlife) }\end{array}$ & 131 & Detailed \\
\hline 5 & Manitou Institute / Crestone Baca Land Trust & 43 & Small, not pursued \\
\hline 6 & Orient Land Trust & 548 & Detailed \\
\hline 7 & San Isabel Land Protection Trust & 189 & Detailed \\
\hline 8 & The Nature Conservancy & 21,025 & Few data provided \\
\hline 9 & U.S. National Park Service & 45,940 & Detailed \\
\hline 10 & U.S. Bureau of Land Management & 35,523 & $\begin{array}{l}\text { Detailed, except game } \\
\text { management unit } 861\end{array}$ \\
\hline 11 & U.S. Fish and Wildlife Service & 23,543 & Detailed \\
\hline 12 & U.S. Forest Service - Pike National Forest & 12,431 & Detailed \\
\hline 13 & $\begin{array}{l}\text { U.S. Forest Service - Rio Grande National } \\
\text { Forest }\end{array}$ & 45,841 & Detailed \\
\hline
\end{tabular}

${ }^{1}$ Some rounding occurred in the original source and during our spatial analyses.

We obtained detailed estimates from NPS of stocking rates on their lands, which were mostly not grazed by livestock. The BLM in Saguache and Alamosa Counties provided detailed grazing leases on allotments. Stocking rates on allotments within Huerfano County (GMU 861) were not available. We assigned a default offtake of $82 \mathrm{~kg} / \mathrm{ha} /$ year to those lands, based on typical offtake on other BLM allotments with similar vegetation and climate. The U.S. Fish and Wildlife Service provided detailed historical and current grazing and stocking patterns on their lands. Lastly, the U.S. Forest Service confirmed that most of their lands within the study area were not currently grazed, with only one active allotment.

After assigning offtake values to each of the land ownership parcels, we sought a means to incorporate the spatial variability known to occur across the parcels while maintaining the offtake indicated for each ownership parcel. A spatial surface portraying ANPP estimates derived from satellite images incorporated the spatial variability we sought. We used that surface to calculate an average net 
primary production by land ownership parcel. We then calculated the deviation from the parcel average for each cell (equal to each acre) in the raster surface. This yielded a surface with values across the map spanning from $746 \mathrm{~kg}$ below the mean to $901 \mathrm{~kg}$ above the mean. The surface was then divided by 901 , yielding a normalized deviation map with values between -1 and 1 (in practice, from -0.827 and 1.0). That surface then contained values that incorporated the spatial variability we sought, and that had an average for each ownership parcel of approximately 0 .

We created a surface that contained the appropriate offtake (for example, $82 \mathrm{~kg} / \mathrm{ha} /$ year) for each land ownership parcel. We then added to that surface, on a pixel-by-pixel basis, a value corresponding to the normalized deviation map times some multiplier. For example, if we used a multiplier of 1, that times the normalized surface would add or subtract up to $1 \mathrm{~kg} / \mathrm{ha} / \mathrm{year}$ (insufficient to capture the spatial variability in productivity we observed). If we used a multiplier of 100, the value added or subtracted would have been less than or equal to $100 \mathrm{~kg} / \mathrm{ha} /$ year, which in practice appeared to make the resulting surface too variable. Objective methods of defining this multiplier would have required highly detailed offtake estimates that were unavailable to us, so we subjectively identified a multiplier of 50 as yielding a reasonable distribution of livestock offtake across the landscape. Most importantly, analyses using the resulting offtake surface to double-check the processes confirmed that the offtake within each of the ownership parcels remained in agreement with the offtake estimated based on the stocking identified by the land managers. The map resulting from applying these methods (fig. 4) may overestimate offtake somewhat, given that some animals that grazed on private lands may also have grazed on lands managed by one of the other entities. But in turn, these methods could have underestimated offtake somewhat as well, given that areas shown as zero grazing (for example, most Forest Service lands) may have been grazed by livestock occasionally (fig. 4).

\section{Other Wildlife Offtake}

Other wildlife in the study area included mule deer, bighorn sheep (Ovis canadensis), and pronghorn. To include these ungulates in the model, we created an offtake map accounting for their forage use (fig. 5). We used CPW Species Activity Data

(http://www.arcgis.com/home/group.html? owner $=$ rsacco\&title $=$ Colorado\%20Parks\%20and\%20Wildli fe\%20-\%20Species\%20Activity\%20Data), which contains digital maps detailing the overall range and seasonal range for ungulate species in Colorado, or we contacted the CPW GIS Unit. Using Species Activity Data range maps, combined with estimates of ungulate population size provided by CPW, we generated forage offtake maps. We obtained estimates of ungulate population numbers from the CPW District Wildlife Manager or Habitat Biologist responsible for that area, and calculated total forage demand generated by the estimated population. We obtained average body weight estimates for ungulates from Wassink (1993; table 2). Daily forage demand for grazing ungulates varies from 2.5 percent of body weight during active forage growth to 1.5 percent during forage dormancy (Holechek and Pieper, 1992), averaging 2 percent. The forage demand generated by each species was then allocated across the landscape. To do this for mule deer, for example, the demand created by the entire population is distributed equally across all of the land within their range for the six summer months and then across only the land in the winter range for six months. Approximately 3,230 deer inhabited the study area (Colorado Division of Wildlife, 2008). For bighorn sheep and pronghorn, the population was more simply distributed across the overall range for 12 months to reflect their seasonal distribution. 


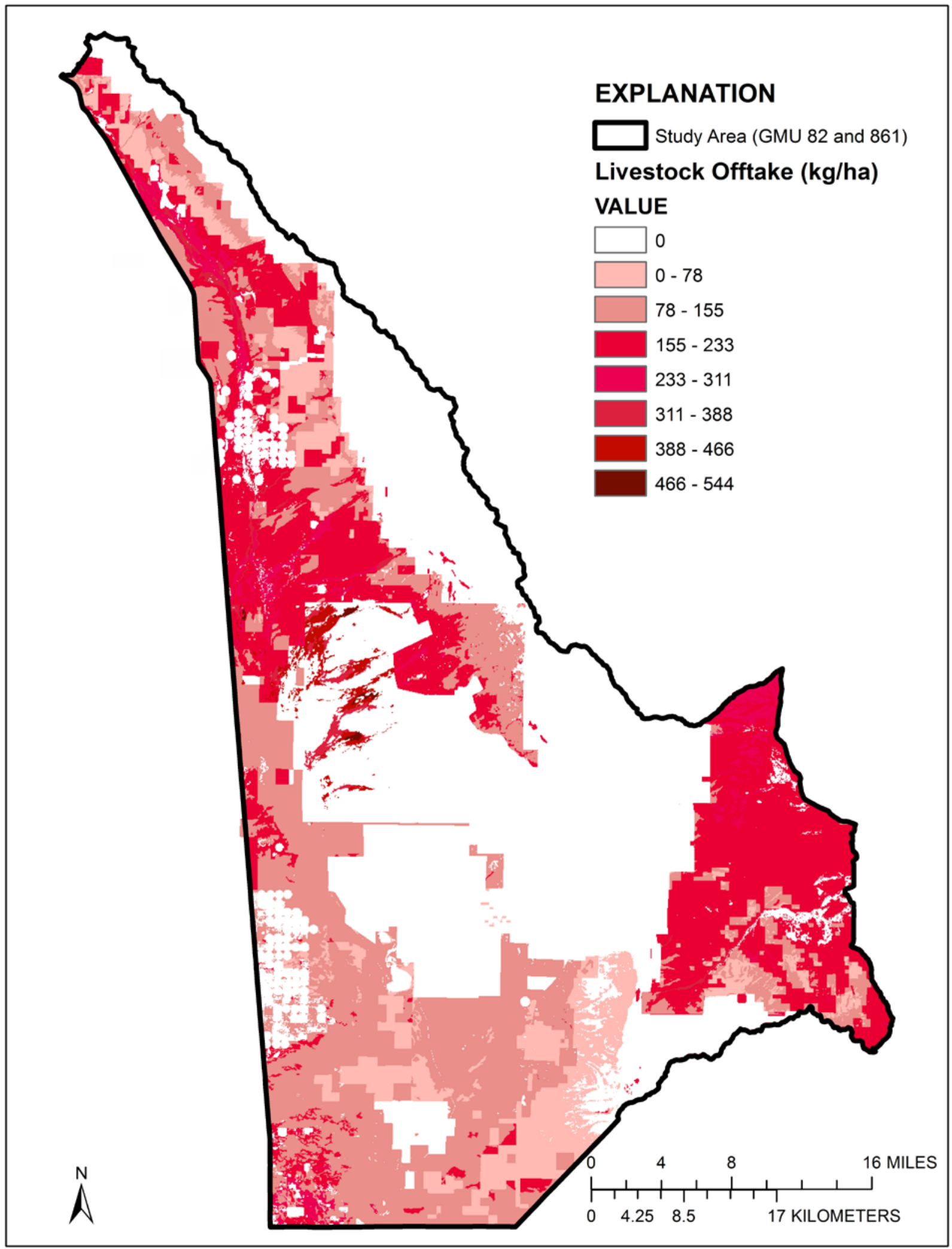

Figure 4. Livestock offtake in $\mathrm{kg} / \mathrm{ha}$ for the study area in the San Luis Valley, Colorado. (GMU, game management unit; kg/ha, kilograms per hectare) 


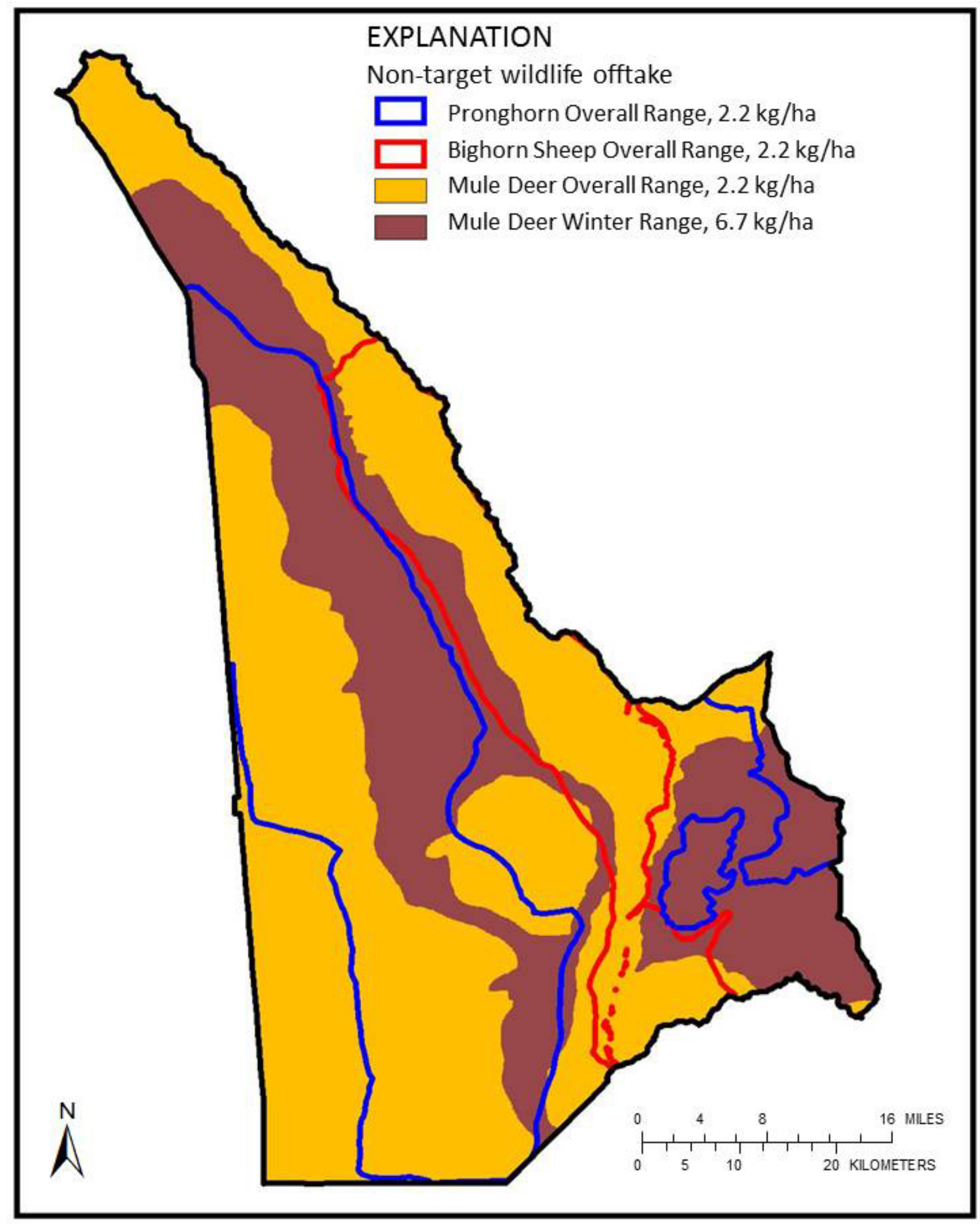

Figure 5. Range of pronghorn, bighorn sheep, and mule deer in the study area. Mule deer are found over the entire study area in summer, and winter range is shown in brown. Amounts used to calculate offtake by other wildlife is also shown. (kg/ha, kilograms per hectare) 


\section{Bison Offtake}

Resource managers were interested in predicting elk carrying capacity using varying bison population sizes ( 0 bison, 1,000 bison, and 2,000 bison). We calculated bison offtake using an average bison weight of $567 \mathrm{~kg}$. Thus, the formula for total offtake by bison, using the average forage demand value of 2 percent (Holechek and Pieper, 1992) was:

Offtake in $\mathrm{kg} / \mathrm{ha} /$ year $=\#$ bison $\times 0.02 /$ day $\times 567 \mathrm{~kg} \times 365$ days $/ 13,074$ ha

Table 2. Average body weights for wild ungulates used for carrying capacity modeling (Wassink, 1993). (kg, kilograms)

\begin{tabular}{lc}
\hline \multicolumn{1}{c}{ Wild Ungulate } & Average Body Weight per Individual \\
\hline Pronghorn Antelope & $45 \mathrm{~kg}$ \\
Bighorn Sheep & $90 \mathrm{~kg}$ \\
Mule Deer & $68 \mathrm{~kg}$ \\
\hline
\end{tabular}

\section{Elk and Bison Ranges}

\section{Elk Range}

To calculate elk carrying capacity, we focused our analyses on areas that were known to be used by elk. We used elk location data collected by NPS, USGS, and CPW from 2005-2007 to determine the elk population-range boundary (fig. 6). Individual elk locations were used to calculate 90 percent kernel home range estimates. Those estimates were then stacked in a GIS to yield relative density maps. Layers were created that showed all areas used by elk in those maps, and from those, the range boundary was created. Because the seasonal variability of range use was very low (high overlap of range use occurred in all seasons), we merged seasonal polygons together to create one unified elk range in the study area (fig. 6). We emphasize that this range is not all the potentially available habitat for elk in GMUs 82 and 861, but more conservatively estimates the habitat carrying capacity for the area known to be used by elk based on radio collar location and survey data (Schoenecker and Lubow, in review). In addition, areas we did not want to make available to elk (irrigation pivots, other agriculture lands in the study area) were removed from the model by subtracting them from available forage.

\section{Bison Range}

Similar to elk, we determined the area used by bison using 14 VHF radio collars (Advanced Telemetry Systems, Isanti, Minnesota) monitored each week from 2005-2007. The range of bison within the fenced Ranch was 13,074 ha. For the elk carrying capacity model, only this 13,074 ha of the Ranch (fig. 7) that was known to be used by bison had forage removed from it. However, for the bison carrying capacity model, the entire Ranch was made available to bison.

\section{Model Calculations}

We used GIS raster-based layers called grids and vector-based layers called polygons to conduct calculations in the model. Each subtraction involved a "grid subtracted from a grid." Summing involved 


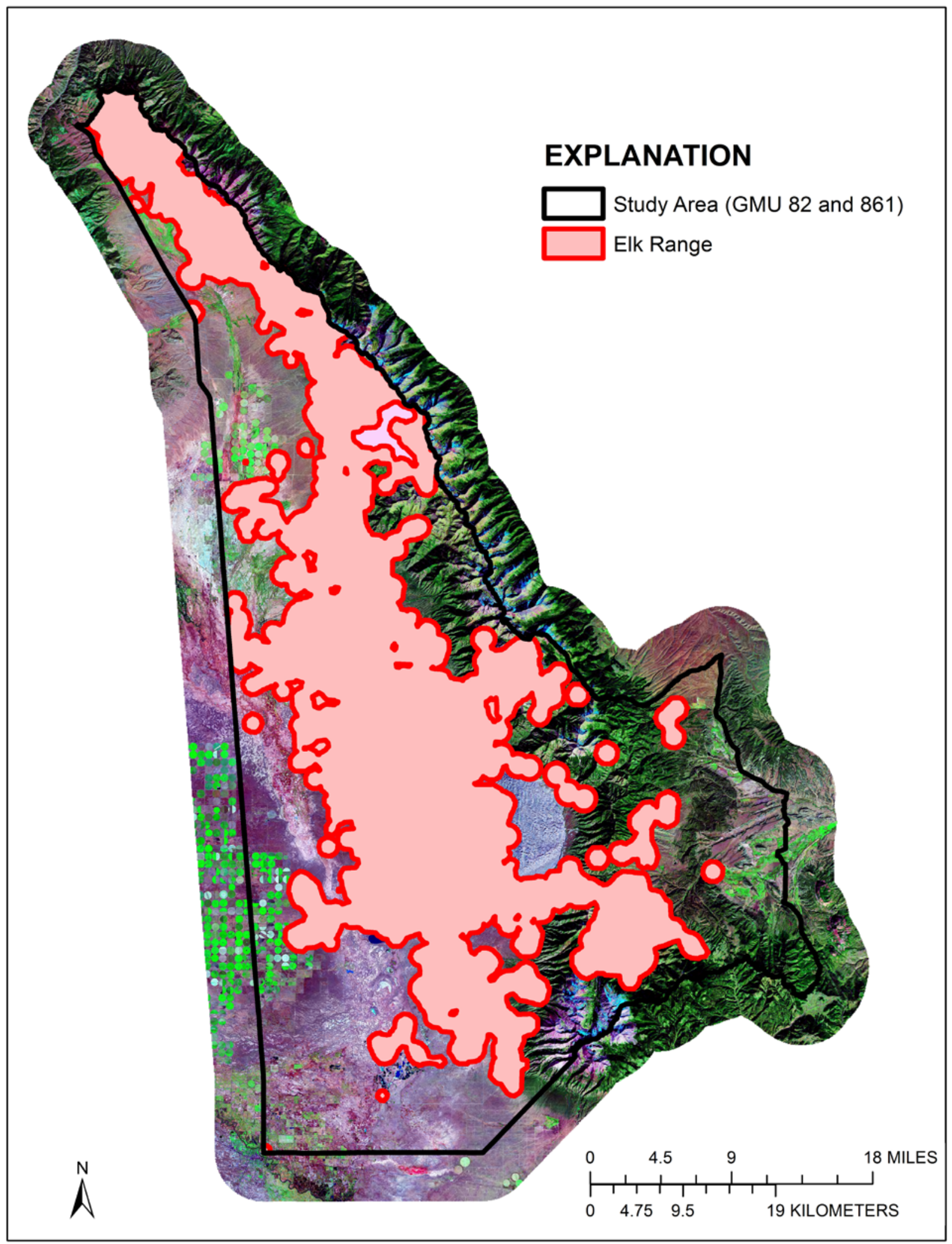

Figure 6. Elk range (area used by elk based on radio collar data), comprising 395,651 acres of the larger study area which is delineated by the black line. (GMU, game management unit) 


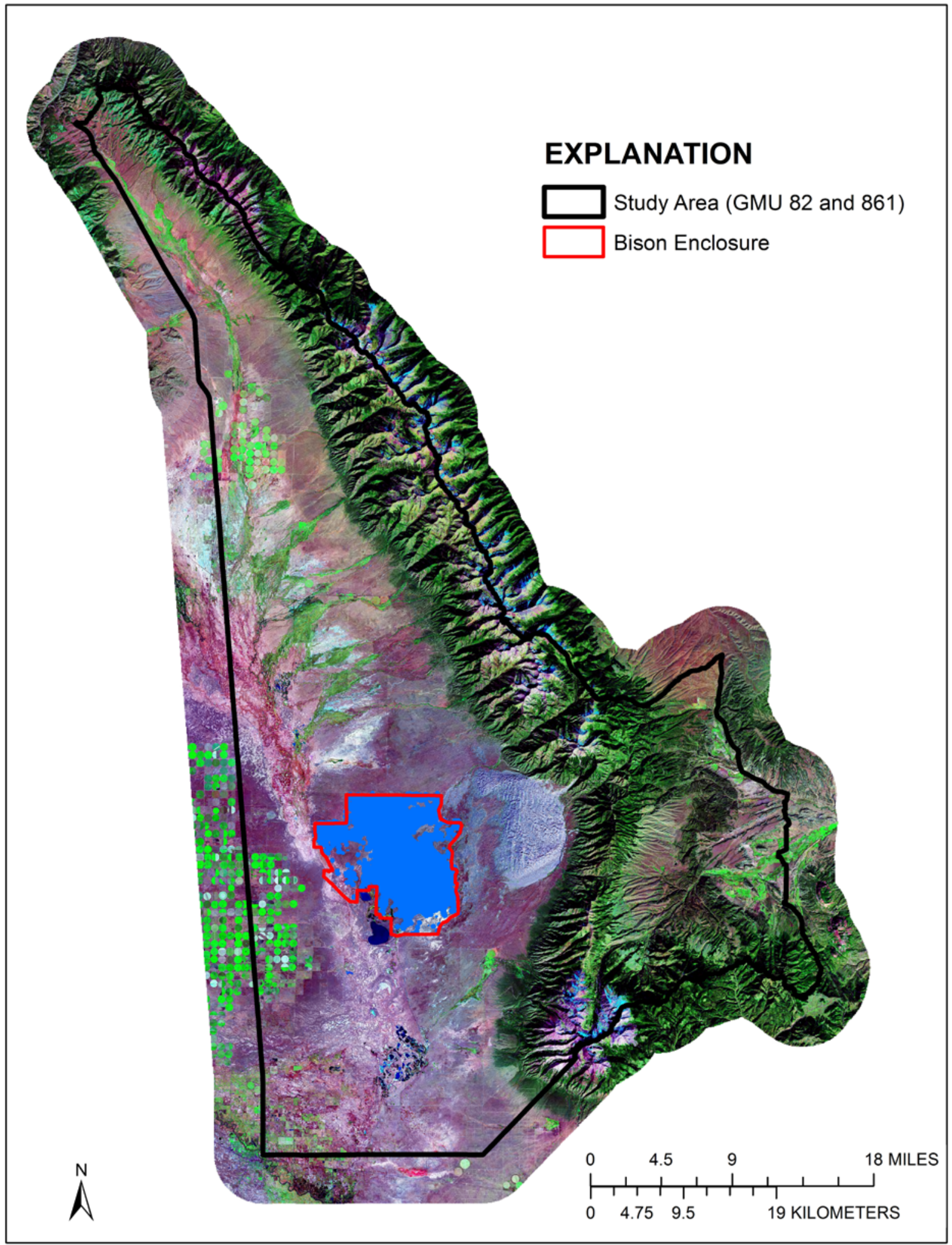

Figure 7. Bison range on the Medano Ranch, Colorado. The red line delineates the fenced area for bison, and the blue polygon delineates their range based on radio collar data collected during 2005-2007. (GMU, game management unit) 
adding up all the forage shown in a grid that fell within a designated polygon. We calculated using the following sequence:

1. Start with Vegetation Production (ANPP) on:

a. Elk carrying capacity model — the entire study area;

b. Bison carrying capacity model — the Medano Ranch.

2. Calculate "Habitat Sustainability Threshold" (the amount of vegetation production that must not be grazed) at three threshold levels, and subtract these values from vegetation production map:

a. Elk carrying capacity model thresholds -75 percent, 71.5 percent, 68 percent;

b. Bison carrying capacity model thresholds - 75 percent, 50 percent, 25 percent.

3. Subtract livestock offtake (elk carrying capacity model only).

4. Subtract offtake from other wild ungulates - mule deer, pronghorn, and bighorn sheep.

5. Subtract:

a. Elk carrying capacity model — subtract bison offtake for varying numbers of bison assuming bison are on the ranch 12 months/year ( 0 bison, 1,000 bison, 2,000 bison);

b. Bison carrying capacity model — subtract elk offtake for varying numbers of elk assuming elk are on the Ranch for 12 months/year ( 0 elk, 500 elk, 1,000 elk, and 1,500 elk).

6. Calculate how much vegetation remains:

a. Elk carrying capacity model—inside the known/used elk range, not within the entire two GMUs;

b. Bison carrying capacity model—inside the entire Medano Ranch.

7. Using the thresholds defined in \#2, calculate how many elk/bison can be fed for twelve months with the amount of vegetation in \#6:

a. Elk carrying capacity — using an average elk weight of $227 \mathrm{~kg}$;

b. Bison carrying capacity_ using an average bison weight of $453 \mathrm{~kg}$.

\section{Model Scenarios}

\section{Baseline Elk Carrying Capacity Model}

We created a "baseline" model scenario for the study area using the following assumptions:

1. Mean precipitation: baseline results, and all scenarios (except for the "climate change" scenario) use mean precipitation as the source for the vegetation-production map.

2. Livestock offtake in a mean precipitation year: although livestock numbers can vary dramatically by forage availability, the baseline model and all scenarios use only one livestock offtake map based on mean precipitation and mean stocking levels.

3. Unvaried numbers of mule deer, pronghorn antelope, and bighorn sheep: these species abundances are never varied in any modeling scenario, so population estimates used are from 2007/2008.

4. 2,000 bison: the approximate number of bison in the study area in 2008 .

5. Normal irrigation and haying on the Baca National Wildlife Refuge. 
After calculating the baseline elk model, we ran several management scenarios to see how elk carrying capacity would be affected by different management actions. We evaluated scenarios to reduce the number of bison on the Medano Ranch, to alter habitat manipulations on the Baca NWR, to evaluate potential impacts from climate change, and to "clip-out" just the federal and TNC lands to see how elk carrying capacity is supported by these landowners.

\section{Bison Carrying Capacity Model}

Baseline assumptions for the bison carrying capacity model were similar to those for the elk model. Vegetation production reflected mean precipitation. Only grazing by mule deer and pronghorn were included since no livestock grazing occurs on the Ranch and ranchlands fall outside the range of bighorn sheep. Some irrigation does occur on the Medano Ranch and the model assumes normal irrigation operations. Management scenarios for the bison model varied the number of elk to determine how changing the size of the elk population would affect carrying capacity for bison on the Ranch.

\section{Results}

\section{Elk Model Results}

Our baseline model indicated that roughly 6,100 elk can be supported in habitats within areas known to be used by elk, with a low threshold of 3,790 and a high threshold of roughly 8,400 (table 3). We found that significantly more elk can be supported if bison numbers are reduced (table 3 ). If resource managers reduce or eliminate the bison herd, elk numbers could conservatively grow to 10,984 (with zero bison) or 8,494 (with 1,000 bison) and still meet habitat carrying capacity limitations for the entire landscape.

Table 3. Estimated elk carrying capacity modeled within elk range in the Great Sand Dunes/San Luis Valley, Colorado study area. Offtake thresholds reflect total offtake rates of all ungulates on the landscape.

\begin{tabular}{cccc}
\hline & \multicolumn{2}{c}{ Estimated elk population size (carrying capacity) } \\
\cline { 2 - 4 } Bison population size & Low threshold & Mid-point threshold & High threshold \\
$(25$ percent offtake) & $(28.5$ percent offtake $)$ & $(32$ percent offtake) \\
\hline 2,000 (baseline) & 3,790 & 6,104 & 8,417 \\
1,000 & 6,181 & 8,494 & 10,808 \\
0 & 8,580 & 10,984 & 13,207 \\
\hline
\end{tabular}

We modeled a management scenario that reduced habitat manipulations on the Baca National Wildlife Refuge. The Baca comprises about 23,472 ha, part of which is irrigated, hayed, and grazed by livestock. For baseline elk carrying capacity, average production across the Baca was $848 \mathrm{~kg} / \mathrm{ha}$. This production value includes the effect of irrigating and haying selected areas on the Baca, which provides roughly $840 \mathrm{~kg} / \mathrm{ha}$ of "leftover stubble" on these irrigated lands after haying. We modeled how removing irrigating and haying on the Baca would affect elk carrying capacity. For this scenario, we returned average production on the Baca to a "native vegetation" level of $672 \mathrm{~kg} / \mathrm{ha}$ that mirrored the average across the landscape surrounding the Baca. We also manipulated livestock grazing on the Baca to evaluate the effect on elk carrying capacity. We found that eliminating irrigating and haying reduced carrying capacity by roughly 700 elk (table 4); we also found that eliminating livestock grazing in addition to cessation of irrigating and haying increased elk carrying capacity by about 500 elk compared to baseline elk carrying capacity (table 4 ). 
We modeled a very simplistic estimate of the potential impact climate change could have on the elk carrying capacity in the study area. For this scenario, we reduced overall vegetation production by 10 percent to account for reduced rainfall during the growing season in the study area (Ray and others, 2008).

Table 4. Estimated elk carrying capacity modeled within elk range in the Great Sand Dunes/San Luis Valley, Colorado study area using various habitat-management scenarios on the Baca National Wildlife Refuge portion of the study area. Model assumes 2,000 bison on the Medano Ranch. Offtake thresholds reflect total offtake of all ungulates on the landscape.

\begin{tabular}{lccc}
\hline & \multicolumn{3}{c}{ Estimated elk population size (carrying capacity) } \\
\cline { 2 - 4 } \multicolumn{1}{c}{ Management scenario } & $\begin{array}{c}\text { Low threshold } \\
\text { (25 percent offtake) }\end{array}$ & $\begin{array}{c}\text { Mid-point threshold } \\
(28.5 \text { percent offtake) }\end{array}$ & $\begin{array}{c}\text { High threshold } \\
\text { (32 percent offtake) }\end{array}$ \\
\hline $\begin{array}{l}\text { No irrigation or haying on the Baca; } \\
\text { livestock grazing at current levels. }\end{array}$ & 3,192 & 5,416 & 7,640 \\
$\begin{array}{l}\text { No irrigation or haying, no livestock. } \\
\begin{array}{l}\text { Irrigation, haying, and livestock } \\
\text { grazing at current levels, but 10 }\end{array}\end{array}$ & 4,373 & 6,597 & 8,821 \\
$\begin{array}{l}\text { percent forage reduction due to } \\
\text { climate change. }\end{array}$ & 2,191 & 4,273 & 6,356 \\
\hline
\end{tabular}

We modeled two scenarios using only federal and TNC lands to determine what portion of elk carrying capacity is supported by these landowners. The first scenario calculated carrying capacity only within the federal and TNC landscape, that is: Great Sand Dunes National Park and Preserve, TNC's Medano Ranch, and the Baca National Wildlife Refuge (see fig. 1). On these lands only, elk carrying capacity was 35 percent of the overall carrying capacity of the entire study area (table 5). For the second scenario, we calculated within the same landscape but with no bison on the Medano Ranch. When bison are not present, elk carrying capacity is roughly 700 animals greater than baseline, or about 11 percent higher (table 5).

Table 5. Estimated elk carrying capacity modeled for only Great Sand Dunes National Park and Preserve, the Medano Ranch, and Baca National Wildlife Refuge. Offtake thresholds reflect total offtake rates of all ungulates on the landscape.

\begin{tabular}{cccc}
\hline & \multicolumn{3}{c}{ Estimated elk population size (carrying capacity) } \\
\cline { 2 - 4 } Bison population size & Low threshold & Mid-point threshold & High threshold \\
$(25$ percent offtake) & $(28.5$ percent offtake) & (32 percent offtake) \\
\hline 2,000 & 971 & 2,038 & 3,104 \\
0 & 5,743 & 6,810 & 7,876 \\
\hline
\end{tabular}

\section{Bison Model Results}

Bison carrying capacity varied based on the number of elk using the Medano Ranch (table 6). Radio collar data from 2005-2007 suggested an average of approximately 500 elk used the Medano for twelve months (K. Schoenecker, Ecologist, U.S. Geological Survey, Fort Collins Science Center, unpublished data), but we cannot be certain. In addition, changes in bison management (increases in bison population size, for example) can influence elk distribution and use of the Ranch. We have no 
way of knowing how these variables change over time and potentially influenced elk distribution and use of the Ranch.

Table 6. Bison carrying capacity on the Medano Ranch at varying numbers of elk. Model calculations assume elk reside on the ranch year-round.

\begin{tabular}{cccc}
\hline & \multicolumn{3}{c}{ Estimated bison population size (carrying capacity) } \\
\cline { 2 - 4 } Elk population size & Low threshold & Mid-point threshold & High threshold \\
$(25$ percent offtake $)$ & $(50$ percent offtake $)$ & $(75$ percent offtake $)$ \\
\hline 0 & 751 & 1,570 & 2,389 \\
500 & 438 & 1,256 & 2,075 \\
1,000 & 246 & 1,065 & 1,884 \\
1,500 & 55 & 874 & 1,693 \\
\hline
\end{tabular}

\section{Discussion}

Under baseline conditions (mean precipitation; current livestock stocking in a year with mean precipitation; wildlife numbers that reflect 2007/2008 population counts; 2,000 bison, and normal irrigation/haying operations on the Baca), our model suggests that a conservative carrying capacity for elk within the areas they use in GMUs 82 and 861 (within the polygons in fig. 4) is 6,104, with a low threshold of 3,790 and a high threshold of 8,417. The population of elk on the study area was approximately 5,000 in 2008/2009 (B. Weinmeister, Terrestrial Biologist, Colorado Parks and Wildlife, oral commun., August 2009; Schoenecker and Lubow, in review). Our model suggests that the landscape is currently being grazed by elk between the low threshold and mid-point for carrying capacity. Because the grazing intensity is lower than the mid-point, the available forage for herbivores is not likely being maximally used across the entire landscape, although hot spots of elk overconcentration or overgrazing may exist. Such hot spots are due to the uneven distribution of elk across the landscape. If managers want to reduce grazing pressure on these habitats, using management options that re-distribute elk or protect sensitive vegetation would likely yield more positive results than focusing on a reduction of the overall numbers of elk. Relying on simple herd-size reductions may not relieve grazing or browsing pressure on sensitive or preferred habitats where elk concentrate. That is, if elk focus browsing pressure in the same areas and their density of use is consistently higher in these areas, reducing overall herd size may have little positive effect on these preferred communities. However, if herd reductions are severe enough, elk densities in preferred habitats would be reduced eventually, but it would be a non-linear response.

When irrigating and haying were eliminated on the Baca NWR, elk carrying capacity decreased because the average production value for "native vegetation" on the Baca $(672 \mathrm{~kg} / \mathrm{ha})$ is lower than the average production value accrued after irrigating and haying $(847 \mathrm{~kg} / \mathrm{ha})$. If livestock were also removed from the Baca, elk carrying capacity would increase from 6,104 animals to 6,597 animals (mid-point threshold), which is a relatively small increase. Management activities on the Baca made an overall plus or minus 10 percent impact on the total elk carrying capacity for the entire study area.

Climate change introduces considerable uncertainty on western landscapes (Frame and Stone, 2012). Cumulative long-term impacts are very difficult to predict. Some global-circulation models predict more annual precipitation by 2050, and some predict less. In general, however, climate change models agree that temperatures will increase, and that seasonal patterns of precipitation will change (Intergovernmental Panel on Climate Change, 2008). Several studies specific to Colorado suggest that 
summer precipitation will decrease as temperatures increase in western Colorado (Ray and others, 2008). The primary ecological driver in arid ecosystems is precipitation (Noy-Meir, 1973, 1979/80; Ellis and Swift, 1988), so a decline in precipitation during the growing season strongly suggests that forage production will also decline. The future under climate change is difficult to predict, and we may already be observing effects. The San Luis Valley has received lower than average precipitation since 2002 according to the Palmer Drought Severity Index. In our scenario, we modeled a 10-percent reduction in forage which substantially reduced elk carrying capacity by about 1,800 individuals. Other types of changes may also occur that are difficult to estimate, including changes in vegetation composition which could shift elk distribution and/or migration patterns. Our model results suggest that climate change has the potential to exert a much greater impact on elk carrying capacity than any management activities pertaining to elk or bison.

In our final scenario, we modeled carrying capacity on just the federal and TNC lands. Although the entire study area can support roughly 6,100 elk, the Park and Preserve, Refuge, and Medano Ranch, can support about 35 percent of that. Removing bison from the Medano increased forage available to elk and thus increased carrying capacity. However, because elk migrate all over the study area, it would be impossible to manage elk just on these federal parcels.

In a study of the effects of elk and bison grazing on vegetation, wetland vegetation types on the Medano Ranch bison range were productive and resilient to grazing (Schoenecker, 2012). For this reason, we used a wide range for calculating habitat sustainability thresholds for the bison carrying capacity model. It is unclear whether the 75 percent offtake level is sustainable year after year, but empirical data suggested it was occurring from 2005-2007. We suggest that habitat sustainability on the Ranch would be better achieved nearer to the midpoint (50 percent offtake level) than at the high threshold. Thus, bison numbers between 874 and 1,570 likely represent a sustainable range of carrying capacity for the Ranch under varying elk numbers. We suggest that further fieldwork and monitoring should be done to measure vegetation production on the Ranch and to estimate sustainable grazing levels in order to refine the bison model. Alternatively, models could be run with a threshold between 50 percent and 75 percent, such as at 60 percent.

\section{Acknowledgments}

We thank the many researchers who have been studying the Great Sand Dunes ecosystem in the past decade. Specifically, we thank those who produced the vegetation map: David Salas of the U.S. Bureau of Reclamation, Mike Artman of the U.S. Fish and Wildlife Service, Joe Stevens of the Colorado Natural Heritage Program, Bev Friessen from USGS, Keith Schulz from NatureServe, and Karl Brown of the National NPS VegMap program. We thank those who tracked and recorded locations of bison and elk and allowed us to create a detailed range map: Katie Hagaman and Julie Mao. Information produced by NRCS, the USGS, the BLM, and others was useful as model inputs. We thank the following individuals for providing information on livestock stocking rates for the lands they own or manage: Kate Shar and Paul Robertson of The Nature Conservancy; Ron Garcia of the U.S. Fish and Wildlife Service; Lisa Van Amburg of the U.S. Forest Service; Doug Simon, Melissa Shawcroft and Tom Grette of the U.S. Bureau of Land Management; Kit Page of the Colorado State Land Board; and several others. Finally, we thank the U.S. National Park Service, the U.S. Geological Survey, and Great Sand Dunes National Park and Preserve for providing funding to support this research, and The Nature Conservancy for unwavering in-kind support. This work was conducted in cooperation with the National Park Service, and in collaboration with the U.S. Fish and Wildlife Service and The Nature Conservancy. 


\section{References Cited}

Colorado Division of Wildlife, 2008, Deer 2007 post hunt population estimates: Denver, Colo., Colorado Division of Wildlife, accessed online July 11, 2014, at http://cpw.state.co.us/Documents/Hunting/BigGame/Statistics/Deer/2007DeerPopulationEstimate.pdf

Coughenour, M.B., 1991, Spatial components of plant-herbivore interactions in pastoral, ranching, and native ungulate ecosystems: Journal of Range Management, v. 44, p. 530-542.

Ellis, J.E., and Swift, D.W., 1988, Stability of African pastoral ecosystems-Alternate paradigms and implications for development: Journal of Range Management, v. 41, p. 450-459.

Frame, D.J., and Stone, D.A., 2012, Assessment of the first consensus prediction on climate change: Nature Climate Change, v. 3, p. 357-359.

Hobbs, N.T., Wockner, Gary, and Singer, F.J., 2003, Assessing management alternatives for ungulates in the Greater Teton Ecosystem using simulation modeling: Fort Collins, Colo., Colorado State University, Natural Resource Ecology Laboratory, Final Report, 63 p., accessed online April 14, 2014, at http://www.nrel.colostate.edu/projects/teton/TBISON10.pdf.

Holechek, J.L, and Pieper, R.D., 1992, Estimation of stocking rate on New Mexico rangelands: Journal of Soil and Water Conservation, v. 47, p. 116-119.

Intergovernmental Panel on Climate Change, 2008, Climate change 2007-Synthesis report: Geneva, Switzerland, Intergovernmental Panel on Climate Change, accessed online July 11, 2014, at http://www.ipcc.ch/pdf/assessment-report/ar4/syr/ar4_syr.pdf.

Meaney, C.A., and Van Vuren, Dirk, 1993, Recent distribution of bison in Colorado west of the Great Plains: Proceedings of the Denver Museum of Natural History Series 3, v. 4, p. 1-10, accessed online August 8, 2014, at http://www.dmns.org/media/368254/pseries3-4.pdf.

Milchunas, D.G., and Lauenroth, W.K., 1993, Quantitative effects of grazing on vegetation and soils over a global range of environments: Ecological Monographs, v. 63, p. 327-366.

Noy-Meir, Imanuel, 1973, Desert ecosystems-Environment and producers: Annual Review of Ecology and Systematics, v. 4, p. 25-51.

Noy-Meir, Imanuel, 1979, Review-Structure and function of desert ecosystems: Israel Journal of Botany, v. 28, p. 1-19.

Ray, A.J., Barsugli, J.J., Averyt, K.B., Wolter, Klaus, Hoerling, Martin, Doesken, Nolan, Udall, Bradley, and Webb, R.S., 2008, Climate change in Colorado-A synthesis to support water resources management and adaptation: Boulder, Colo., University of Colorado, Cooperative Institute for Research in Environmental Sciences, 53 p.

Salas, D.E., Stevens, Joe, Schulz, Keith, Artmann, Mike, Friesen, Beverly, Blauer, Steve, Schweiger, E.W., and Valdez, A.D., 2011, Vegetation classification and mapping project report-Great Sand Dunes National Park and Preserve: Fort Collins, Colo., National Park Service Natural Resource Report, NPS/ROMN/NRR-2011/341, 117 p.

Schoenecker, K.A., 2012, Ecology of bison, elk, and vegetation in an arid ecosystem: Fort Collins, Colo., Colorado State University, Ph.D. dissertation, 91 p.

Schoenecker, K.A., and Lubow, B.C., in review, A hybrid population estimation model for elk (Cervus elaphus) in a cold desert ecosystem: Journal of King Saud University_-Science_-Special Issue on Abundance Estimates in Arid Environments.

Simonds, W.J., 1995, The San Luis Valley Project: U.S. Bureau of Reclamation, Reclamation Project Histories, accessed online April 14, 2014, at http://www.usbr.gov/history/sanluisv.html.

Singer, F.J., Symonds, K.K., Coughenour, M.B., and Norland, J.E., 2004, Elk biology and ecology before and after the Yellowstone fires of 1988, in Wallace, L.L., ed., After the fires-The ecology of change in Yellowstone National Park: New Haven, Conn., Yale University Press, p. 117-142. 
Swift, L.W., 1945, A partial history of the elk herds of Colorado: Journal of Mammalogy, v. 26, p. 114-119.

Theobald, D.M., Peterson, Nathan, and Romme, William, 2004, The Colorado vegetation modelUsing national land cover data and ancillary spatial data to produce a high resolution, fineclassification map of Colorado: Fort Collins, Colo., Colorado State University, Natural Resource Ecology Laboratory, 45 p.

Theobald, D.M., Wilcox, Grant, Linn, S.E., Peterson, Nathan, and, Lineal, M.M., 2008, Colorado ownership, management, and protection v7 database: Fort Collins, Colo., Colorado State University, Department of Human Dimensions of Natural Resources and Natural Resource Ecology Lab.

U.S. Department of Agriculture, various years, Census of Agriculture: Washington, D.C., U.S. Department of Agriculture, National Agricultural Statistics Service, accessed online 8 August 2014, at http://www.agcensus.usda.gov.

Walker, M.D., Webber, P.J., Arnold, E.H., and Ebert-May, Diane, 1994, Effects of interannual climate variation on aboveground phytomass in alpine vegetation: Ecology, v. 75, p. 393-408.

Wassink, J.L., 1993, Mammals of the Central Rockies: Missoula, Mont., Mountain Press Publishing Company, $176 \mathrm{p}$.

Weisberg, P.G., Hobbs, N.T., Ellis, J.E., and Coughenour, M.B., 2002, An ecosystem approach to population management of ungulates: Journal of Environmental Management, v. 65, p. 181-197.

Wockner, Gary, Boone, Randy, Hobbs, N.T., and Freddy, Dave, 2008, The Habitat Assessment Model - A tool to improve wildlife habitat management: Fort Collins, Colo., Colorado State University, Natural Resource Ecology Laboratory, 132 p., accessed online July 11, 2014, at http://warnercnr.colostate.edu/ rboone/pubs/HAM_Manual_Nov_2008.pdf. 